\title{
The Study on Government Credibility Construction by Reviewing Public Events
}

\author{
Xiaohua Yang ${ }^{1} \& \mathrm{Lu} \mathrm{Jin}^{2}$ \\ ${ }^{1}$ School of Social Science, Shanghai University of Engineering Science, Shanghai, China \\ ${ }^{2}$ School of Management, Shanghai University of Engineering Science, Shanghai, China \\ Correspondence: Lu Jin, School of Management, Shanghai University of Engineering Science, Shanghai, ON., Long \\ Teng Road No.333, China. Tel: 86-139-1852-5665. E-mail: shirley_jin0829@126.com
}

This work is supported by Ministry of Education (10YJC630312), and university project fund (2011Q25).

Received: December 9, 2013 Accepted: December 18, 2013 Online Published: December 21, 2013

doi:10.5430/wjss.v1n1p58 URL: http://dx.doi.org/10.5430/wjss.v1n1p58

\begin{abstract}
Public events appear constantly in the period of social transformation, which leads directly to the government-the main body of social management. Some public events exposed the lack of government credibility which is directly related to the effect of government's democratic governance, social credit system, the process of democracy and law, and put forward a greater challenge to the government management. To enhance the credibility, the government must improve information disclosure mechanism, supervise system reform, actively change government function, establish a set of scientific, reasonable, effective policy, decision-making mechanism, and continuously improve the quality of civil servants, etc.
\end{abstract}

Keywords: public events, government, credibility

\section{Introduction}

Due to the development of network information today, some individual incidents easily lead to social diffusion effect, even become social public events and arouse social public attention so that the government is increasingly questioned and distrusted by the public. Some typical events have occurred this year, for instance, "a large number of passengers stranded in Kunming airport because of fog event" occurred on January 3rd, causing large-area flight delays, with about 7500 people passengers stranded in the terminal. The airport official micro-blog issued the first fog warning information 5 hours later after the fog, however, with the flight information unknown, logistical supply deficient, mobile phone and network signal instable, the fog event led to the stranded passengers' mood swings, fights and even odd scuffle. The airport and airline fail to timely warning, information communication capacity and the staff's inability to deal with crisis problem are the main reasons. In the "officer Lai, Guangdong Zhanjiang party and government organs owe 18.5 billion yuan project money" event, debt for years, but have no responsibility and still exceed the standard to enjoy luxury cars and buildings, which seriously damaged party and government's reputation and also the rule of faith. The event of Henan Wangluozhen government owed 700000 "pig's trotters" was exposed in October, which reflected the town government's reception against the rules in recent years. These events have caused extensive attention of the society and people's great dissatisfaction. All issues points to government's dereliction of duty and "lazy politics", which reflected people's condemn and dissatisfaction with the local government and developed into suspicion and distrust to the government, exposed the lack of government credibility, causing further loss credibility of the government. These events have enabled us to think about the many problems in the construction of the government credibility.

\section{The Government Credibility is the Cornerstone of Social Credibility System}

The credibility of the government refers to the recognition and trust degree of government obtained from the public, reflects the government's credit, the authority and the people's satisfaction with the government, directly affects the functions of the government and the ruling efficiency, related to the establishment of social credit system, while the social credit system closely links with the social benign operation and coordinated development. Because of different subjects, the social credit system can be divided into four categories, judicial authority (authority of the law), 
government(body of Management) credibility, the credit market (operators) integrity and social (social relations and social populace) integrity, and as a legitimate subject of power and main body of social management, the government's credibility acts as a banner in the social credit system its credibility, the cornerstone in the establishment of the social credit system, so government must administrate honestly. That is, the government should be first honest and trustworthy, say the truth, will continue to honor their commitments, shape the image of credible government and service government, enhance the credibility, realize the legitimacy of right assigned to by people, thus obtain public recognition on the basis and play the government's role of the "helm" duties in promoting the construction of social credit system.

\section{Analysis of the Reasons of Lack of Government Credibility}

There are many causes for the loss of government credibility, both the top system design and the practical operation. Here summed up in the following points:

\subsection{The Non-transparent Information in Government Management}

Currently the government information publicity construction is advancing, but far from to meet the public demand for the right to know: first, the government did not have a clear scope of information release, which is mainly through routine and periodic disclosure, the official microblog and the application of publicity mode. Second, with the deepening of modern social life, the traditional information release field and path can't meet the information need of people related to their own interests, thus make people produce relative deprivation and group anxiety in society. Third, the government's conservative information release form makes people mistakenly believe that the government had lied, resulting in being cheated and deprivation, which triggered public distrust and discontent to government, one of the reasons for the lack of government credibility.

\subsection{The Supervision Mechanism and Accountability Mechanism is not Perfect}

As the British scholar Acton said: "power corrupts, and absolute power corrupt absolutely", the lack of supervision mechanism and accountability mechanism will inevitably lead to the alienation of power, cause undesirable tendencies of government to act irresponsibly. Problem one, existing supervision mechanism is mostly top-down supervision, lack of bottom-up supervision, while social supervision and the supervision from people is far from enough. The current major public events appeared in society often come from the latter, and many problems exposed reflect the function of bottom-up monitoring role. Problem two, existing supervision is more party's circular supervision, leading to "shield" "secretive" psychological tendency, and the so-called "sharing weal and woe" will produce such cases as in harbor and collusion, etc.. The three, the existing system of accountability is directed to problems, or the accountability strength is not enough, therefore, causing the adverse consequences and loss. The above problems will inevitably damage the credibility of the government.

\subsection{The Boundary of Government Responsibility Needs to be Clarified}

With the continuous development of modern society, the role and functions of government have changed greatly and the government should adjust the thinking, from "almighty government" to "limited government", from "big housekeeper" to the "night watchman". Even though with the constant adjustment and reform, the current government management still exists boundary vague zone in transition. The government of the tube what, shouldn't care what, there should be a clear positioning of their roles, there is a clear division of management field. Do not use the "Only for profit" business thinking to manage state. For example, the government tends to spend great efforts operating land management rather than the management in the field of environmental protection of the whole society, especially with the worsening environment today, which drama the public discontent with the government, reducing the government's credibility.

\subsection{Some Government Officials' "Official Standard” Thought, Damaged the Image of Government}

Some government officials, because of their low quality, cannot fully understand the central policies and regulations, leading to the correct policies and regulations' aliasing, such as unauthorized interception appropriated by the state in some township government in Inner Mongolia and Gansu a few years ago the "returning farmland to forest, returning farmland to the people", which caused strong resentment among the local villagers. Although some of the township government staff did not pocket the money, which was used for school education, it also reflected the grass-roots government staff's professional quality to be improved. Nowadays a post "proof of residence, why is it so hard to get for", arouse a lot of people's heat and resonance, which showed that certain government departments and staff's bureaucracy. These problems have severely undermined the credibility of the government. 


\subsection{People's Lack of Faith during the Period of Social Transformation}

Our country is now in comprehensive transition period from planned economy to market economy with the multiple conflicts of interest. During the period of planned economy, the public belief is loyal, loyal to the party, loyal to the country, loyal to the people. Under the condition of market economy, people's faith is credit, emphasized on the reciprocity of rights and obligations. During the period of social transformation, from the loyal faith to credit, the diversity of interests makes some people lack of belief, neither believe in loyalty nor credit. In reality and social development, when the realization of public interest is blocked, the more dissatisfied emotion points to the government, which also caused the loss of credibility of the government.

\section{Methods to enhance the credibility of the government}

The government credibility contains three elements, the government--subject, the public--object and the bridge--effective connection between the government and the public. To enhance the government's credibility, the essence is require government, as management subject, to establish the harmonious relationship with the people through active acts, thus gaining recognition, trust and support of people and achieving an orderly political philosophy of the government and the ruling target. In the actual development, the government may take the following measures:

\subsection{Continue to Promote Publicity of Government Information}

At present, the government released the information mainly by means of the news spokesman system (regular release or important events release), official micro blogging, information publicity system by application. In modern society, public awareness is growing, which requires the government changes with the times, meet the public demand, release authentic, timely and comprehensive information . Just as the 18th CPC National Congress Report has pointed out "let the power operate in the sunshine". First of all, the government should pay attention to the information disclosure, and the body is subject to the public domain of the public authorities. Secondly, the content of government information publicity should have a clear definition, which can use "negative list system" similar to FTA to disclose information. Such information as personal privacy, commercial secrets, state secrets, etc, can be classified into the negative list, while other information should be public, such as information related to major public interests and people's livelihood decision procedure .

4.2 To Develop a Set of Scientific, Reasonable, Effective Decision-making Mechanism so as to Ensure the Continuity of Policies

Decision-making mechanism existing often divorced from reality because the decision is decided by the People's Congress at all levels of government and lack of basic voice and participation of people. Such decision, even if the decision procedure is correct, because of the low participation and low democratic level in the decision, also can affect decison's enforcement and bring people's dissatisfaction and complaints. Just as the" 3 public funding " problems people are concerned about, fiscal and taxation information transparency issues, the public, as taxpayer obligations, at the same time also hope to enjoy the taxpayer's right to know. At present in some policy and decision making, the administrative color is thick, such as the holiday office of the State Council's holiday arrangement rules, which reflect the tendency of strong administration, suffering people 's criticism.

\subsection{The Government Supervision Mechanism and Accountability Mechanism is to be Improved}

Previously, except the Central Commission for Discipline Inspection, the Commission for Discipline Inspection at all levels of government are produced by the People's Congress at the same level, and report to the superior level for appointment, which easily lead to adverse consequences of protecting each other and is not conducive to the effective supervision. With the reform of the current regulatory system, the People's Congress at the higher level producing lower commission for Discipline Inspection can eliminate disadvantages, separation of powers, based on human rights, from the matters, is conducive to the supervision in place and effective enforcement. Such "officer Lai" event as Guangdong Zhanjiang party and government organs owed 18.5 billion yuan project funds fully exposed the government oversight and account ability mechanism are not perfect.

\subsection{Improve the Hearing System in Administrative Decision}

The decision of the hearing system is helpful to improve the credibility of the government. In the policy-making, listen to the voice from the grassroots and make decision-making scientific and rational. Avoid "professional hearing officer" phenomenon, or hearing system become delivery channel for the government or group interest. In order to avoid the tendency of hearing system separating from the masses, the hearing system should have democratic and transparent procedures. Representative in hearing system should represent the public, and also is directly related so 
as to establish the social supervision and information feedback mechanism in the hearing.

\subsection{Fully Play the Role of New Media during the Change of the Government's Functions}

The government should have clear role and identity identification, learn to delegate, realize change "from the almighty government to the limited government", and strive to create legal government and service-oriented government. Meanwhile, implement the effectiveness of management through the use of new media. The government can create more channels and platform of communication with the public, dissolve barriers, differences and misunderstanding because communication is the most rational, most effective method to solve the contradiction and misunderstanding. This requires the government to further promote the use of e-government, government website, the official micro-blog, new media and other communication channels and platform for information collection, collation, release and management in order to achieve communication between the government and public, enhance the public trust in government, realize soundlessly management objective.

\subsection{Improve the Government Staff's Professional Quality}

All government functionaries is the carrier of the government image and credibility of the government, and the special status enlarge government staff's utility, the so-called "the success or failure of the affair is all due to the very same person", so the government staff should overcome the "official standard" thought, advance with the times, enforce law in the frontline, shape the consciousness and image of public servants. Government departments can promote the human and flexible working patterns, with the public's interests as the starting point, constantly improve the credibility and influence.

\section{Conclusion}

In short, the promotion of the government credibility needs government to combine the system perfection of top design level with practical work of the practice level, that is, continue to promote government information disclosure, lay down scientific, reasonable, effective decision-making mechanism, and constantly improve the government's regulatory system and hearing system, make full use of convenient and efficient characteristics of modern media, pay attention to improve the transformation of government functions and the quality of government staff, enhance the government's credibility, etc.

\section{Reference}

Geng, L. P. (2011). On the lack of credibility of the government and the construction from the public events. Social Scientists, 7, 124-126.

Hong, Z. (2011). Reshaping the credibility of the local government under the state of public crisis management. Journal of Northwest Normal University (Social Science Edition), 7, 117-110.

Song, W. Q. (2013). Enhance the credibility of local government and administrative decision hearing system. Gansu Social Science, 1, 226-229. 